\title{
Possible health effects of liquefied petroleum gas on workers at filling and distribution stations of Gaza governorates
}

\author{
M.M. Sirdah, ${ }^{7}$ N.A. Al Laham ${ }^{2}$ and R.A. ElMadhoun ${ }^{3}$
}

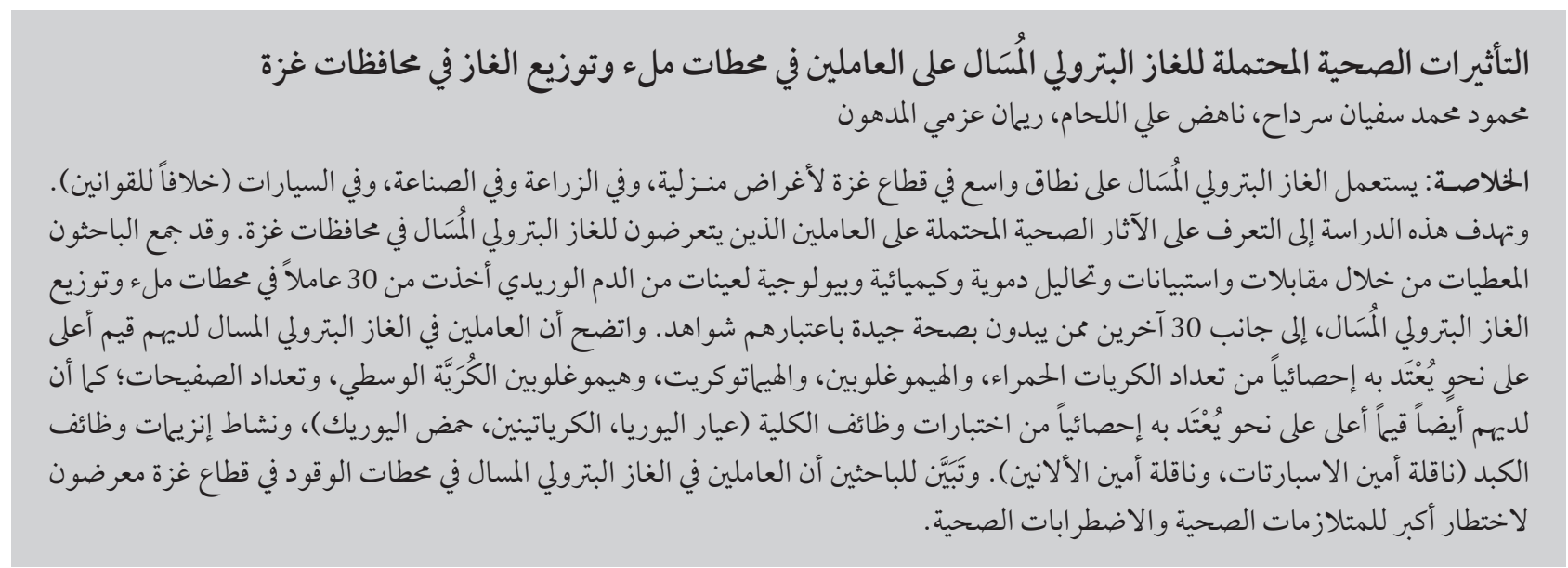

ABSTRACT Liquefied petroleum gas (LPG) is widely used in the Gaza Strip for domestic purposes, in agriculture and industry and, illegally, in cars. This study aimed to identify possible health effects on workers exposed to LPG in Gaza governorates. Data were collected by a questionnaire interview, and haematological and biochemical analyses of venous blood samples were made from 30 workers at filling and distribution stations and 30 apparently healthy controls. Statistically significant differences were found in all self-reported healthrelated complaints among LPG workers versus controls. LPG workers had significantly higher values of red blood cell counts, haemoglobin, haematocrit mean corpuscular haemoglobin and platelet counts. They also had significantly higher values of kidney function tests (urea, creatinine and uric acid) and liver function enzyme activities (aspartate aminotransferase and alanine aminotransferase). LPG workers at Gaza Strip petroleum stations are at higher risk for health-related symptoms and clinical abnormalities.

Effets potentiels du gaz de pétrole liquéfié sur la santé des employés des stations-service dans les gouvernorats de Gaza

RÉSUMÉ L'utilisation du gaz de pétrole liquéfié (GPL) est très répandue dans la Bande de Gaza pour des usages domestiques, en agriculture et dans l'industrie mais aussi illégalement pour les voitures. La présente étude visait à identifier les effets potentiels du GPL sur la santé des employés exposés dans les gouvernorats de Gaza. Des données ont été recueillies par questionnaire au cours d'entretiens. Des échantillons de sang veineux ont été prélevés auprès de 30 employés de stations-service et de 30 témoins en bonne santé apparente à des fins d'analyses hématologiques et biochimiques. Des différences statistiquement significatives ont été observées dans tous les résultats des employés de stations-service de GPL ayant autodéclaré des problèmes de santé par rapport aux résultats d'analyses des témoins. Les employés exposés au GPL présentaient des valeurs nettement supérieures pour la numération érythrocytaire, I'hémoglobine, I'hématocrite, la teneur corpusculaire moyenne en hémoglobine et la numération plaquettaire. Les résultats de leur bilan de la fonction rénale (urée, créatinine, et acide urique) et de leur bilan de l'activité fonctionnelle des enzymes hépatiques (aspartate aminotransférase et alanine aminotransférase) étaient aussi nettement plus élevés. Les employés des stations-service de la Bande de Gaza exposés au gaz de pétrole liquéfié courent un risque plus élevé de présenter des symptômes liés à la santé et des anomalies cliniques. 


\section{Introduction}

The Gaza Strip of Palestine is one of the most densely populated areas in the world. Its economy is mainly dependent on agriculture, fishing, government and relief agency employment and small industries $[1,2]$. In Gaza liquefied petroleum gas (LPG) is used as a fuel for household purposes that include cooking and heating. This is a mixture of commercial propane and butane gases obtained from crude oil in petroleum processing plants, liquefied by pressurizing and cooling [3], and for safety purposes contains a sulfur-based odorizing agent to allow leaks to be more easily detected [4]. Recently, LPG has become used, illegally, as a fuel for cars in the Gaza Strip.

This was a pilot study to evaluate the general health status of workers at petroleum filling and distribution stations with exposure to LPG in Gaza governorates and to determine which of the selected biochemical and haematological parameters were associated with occupational exposure to LPG. The study followed common tools recommended for initial toxicological investigation due to exposure to hazardous substances including a questionnaire interview, blood analysis, determination of liver enzyme activities and evaluation of kidney function [5-9].

\section{Methods}

\section{Study design and sample}

This was a cross-sectional, descriptive study in which workers exposed to LPG were compared with a health control group. The target of the present work comprised all the workers at LPG filling and distribution stations in Gaza governorates. The number of workers in each governorate was selected according to the number of LPG stations and the number of LPG workers in these stations. The sample size was 30 LPG workers and 30 apparently healthy individuals as a control group. The inclusion criteria for the cases were: residence in the Gaza Strip, age $\geq 21$ years, at least 3 years of continuous working at LPG stations, daily working hours $\geq 6$ hours and no previous history of respiratory diseases. The inclusion criteria for the control group were: residence in the Gaza Strip, age $\geq 21$ years, no work-related exposure to LPG, apparently healthy and no previous history of respiratory diseases. The control group were gathered from Palestinian employees at Al Azhar University, Gaza. Subjects in the exposed and unexposed groups were matched by sex, age and governorate.

The study was approved by the research and ethical committee at the department of biology, Al Azhar University, Gaza. Inclusion in the study was voluntary and confidential; no personal identifiers were presented or discussed. All ethical considerations were maintained, including respect of subjects, legitimacy and confidentiality. All participants signed a consent statement at the start of the study.

\section{Data collection}

\section{Questionnaire}

The subjects were interviewed to fill the study questionnaire. It was a closeended questionnaire, constructed and performed in Arabic language, and was designed based on standard tools for screening for hazardous exposure $[10,11]$. It included items about sociodemographic data (sex, age, governorate, residence, marital status); general descriptive characteristics (education level, working profile, smoking), as well as items about health status and complaints that could be linked to LPG exposure (presence of chronic diseases, eyes and skin symptoms, headache and fatigue, presence of common respiratory problems such as morning cough, difficulties in breathing and shortness of breath, sneezing and chest pain). The items and components of the questionnaire were pilot tested for criterion validity and content validity.

\section{Laboratory data}

We screened the subjects for complete blood counts (CBC), activities of liver function enzymes [aspartate aminotransferase (AST) and alanine aminotransferase (ALT)], and kidney function tests (creatinine, urea and uric acid) [5-9].

Venous blood specimens $(5 \mathrm{~mL})$ were collected from individuals into K3-EDTA tubes and serum vacutainer tubes. CBC were performed within 2-4 hours of collection using an autoanlayser (Cell-Dyn 1800 Sapphire, Abbott Diagnostics) and included the following main parameters and indices: white blood cell (WBC) count, red blood cell (RBC) count, haemoglobin $(\mathrm{Hb})$ concentration, haematocrit $(\mathrm{Hct})$ percentage, mean corpuscular volume (MCV), mean corpuscular haemoglobin $(\mathrm{MCH})$, mean corpuscular haemoglobin concentration (MCHC) and platelets count (PLT).

Sera obtained by centrifugation at $3000 \mathrm{rpm}$ for $15 \mathrm{~min}$ were used for determination of AST, ALT, creatinine, urea and uric acid, using the commercially available Biosystems reagent kits.

\section{Data analysis}

The data from the questionnaire, $\mathrm{CBC}$ and biochemical quantization were tabulated, encoded and then statistically analysed using SPSS, version 15. Comparisons between the LPG workers and controls in the mean and standard deviation (SD) values of the selected haematological and biochemical parameters were made using the independent $t$-test analysis. For determination of the significant difference between 2 population proportions, the $z$-test was used. $P$-value of $<0.05$ was considered statistically significant.

\section{Results}

The study population was 60 males, including 30 workers of LPG stations and 30 apparently healthy individuals as the comparison group. The ages of the subjects ranged between $22-56$ years 
old, with a mean age of 33.8 (SD 9.4) years. No statistically significant differences were detected between the age of LPG workers [34.4 (SD 9.3) years] and that of the healthy group [33.2 (SD 9.6) years] (independent $t$-test, $P=0.616$ ).

\section{Health-related complaints}

The general health status and selfreported health-related complaints of LPG-exposed workers and controls are listed in Table 1. The results showed significantly higher rates of nearly all health status items in LPG workers compared with controls, especially the items about experiencing headache or fatigue in work, eye itches, redness, pain, skin itches, redness and rash $(P<0.001)(z$-test $)$.

LPG workers also had significantly higher rates of respiratory complaints, such as fatigue or pain during climbing stairs, repeated sneezing during working hours, shortness of breath in poorly ventilated room and shortness of breath in the workplace $(P<0.001)$ (Table 1$)$.

\section{Haematological parameters}

LPG-exposed workers were found to have significantly higher values of RBC,
$\mathrm{Hb}, \mathrm{HCT}, \mathrm{MCH}, \mathrm{MCHC}$ and PLT compared with the controls (independent t-test, $P<0.05$ ) (Table 2), while the mean WBC was significantly lower in workers compared with controls.

\section{Liver and kidney function tests}

The mean values of serum AST and ALT were significantly higher among LPG workers [34.7 (SD 5.39) U/L and 32.7 (SD 4.30) U/L respectively] compared with controls [16.6 (SD 4.48) $\mathrm{U} / \mathrm{L}$ and 14.6 (SD 4.15) U/L respectively] (independent $t$-test $P<0.05$ ) (Table 3). Moreover, the mean values of serum urea, creatinine and uric acid were all statistically significantly higher among LPG workers versus controls (independent $t$-test, $P<0.001$ ).

\section{Other comparisons}

Among the LPG-exposed workers, there were no statistically significant differences in the selected haematological (CBC) and biochemical parameters (AST, ALT, urea, creatinine, uric acid) between smokers and non-smokers, married and unmarried workers and filling and distribution workers (data not shown).

\section{Discussion}

This study in the Gaza Strip could be considered as a pilot study, which aimed to determine the potential effects of LPG exposure on the health of gas filling and distribution workers. Most of the men engaged in the present work were in the third decade of life. The LPG workers and healthy controls were matched for age to control for potential effect of age on the health status of any group of the study subjects.

The self-reported health-related complaints that could be associated with LPG exposure were significantly more common among the workers than the controls. Scientific studies in different settings showed similar results as our study, especially concerning health complaints related to respiratory system efficiency [12-14]. Thesehealth-related complaints of LPG workers are likely to be due to the pharmacological effect of LPG. Inhalation of gaseous propane (the major component of LPG) is known to cause dizziness, nausea, vomiting, confusion, hallucinations and a feeling of euphoria [15], and to suppress

\begin{tabular}{|c|c|c|c|c|c|}
\hline \multirow[t]{2}{*}{ Health status } & \multicolumn{2}{|c|}{$\begin{array}{l}\text { LPG workers } \\
\quad(n=30)\end{array}$} & \multicolumn{2}{|c|}{$\begin{array}{c}\text { Controls } \\
(n=30)\end{array}$} & \multirow[t]{2}{*}{$\begin{array}{l}P \text {-value } \\
\text { (z-test) }\end{array}$} \\
\hline & No. & $\%$ & No. & $\%$ & \\
\hline \multicolumn{6}{|l|}{ General health status } \\
\hline Having chronic disease & 8 & 26.7 & 5 & 16.7 & 0.356 \\
\hline Currently having health problems & 12 & 40.0 & 4 & 13.3 & 0.019 \\
\hline Believe health problems due to work & 11 & 36.7 & 0 & 0.0 & $<0.001$ \\
\hline Health problems disappear in holidays & 3 & 10.0 & 2 & 6.7 & 0.647 \\
\hline Experiencing headache or vertigo at work & 18 & 60.0 & 3 & 10.0 & $<0.001$ \\
\hline Experiencing eye itch, redness, pain & 30 & 100.0 & 2 & 6.7 & $<0.001$ \\
\hline Experiencing skin redness, rash, itch & 18 & 60.0 & 1 & 3.3 & $<0.001$ \\
\hline \multicolumn{6}{|l|}{ Presence of respiratory problems } \\
\hline Morning cough, shortness of breath & 23 & 76.7 & 20 & 66.7 & 0.399 \\
\hline Fatigue or pain during climbing stairs & 15 & 50.0 & 3 & 10.0 & $<0.001$ \\
\hline Repeated sneezing during working hours & 12 & 40.0 & 0 & 0.0 & $<0.001$ \\
\hline Difficulty breath from nose & 20 & 66.7 & 13 & 43.4 & 0.071 \\
\hline Shortness of breath in poorly ventilated room & 20 & 66.7 & 6 & 20.0 & $<0.001$ \\
\hline Shortness of breath in the workplace & 24 & 80.0 & 9 & 30.0 & $<0.001$ \\
\hline
\end{tabular}




\begin{tabular}{|c|c|c|c|}
\hline Parameter & $\begin{array}{c}\text { LPG workers } \\
\text { Mean (SD) }\end{array}$ & $\begin{array}{c}\text { Controls } \\
\text { Mean (SD) }\end{array}$ & $\begin{array}{c}P \text {-value } \\
(t \text {-test) }\end{array}$ \\
\hline WBC $\left(\times 10^{9} / \mathrm{L}\right)$ & $4.71(0.87)$ & $7.90(1.64)$ & $<0.001$ \\
\hline $\operatorname{RBC}\left(\times 10^{12} / \mathrm{L}\right)$ & $6.27(0.76)$ & $4.68(0.53)$ & $<0.001$ \\
\hline $\mathrm{Hb}(\mathrm{g} / \mathrm{dL})$ & $16.3(0.75)$ & $14.4(0.72)$ & $<0.001$ \\
\hline Hct (\%) & $51.1(4.37)$ & 41.9 (2.39) & $<0.001$ \\
\hline MCV (fL) & $88.2(2.78)$ & 87.7 (3.39) & 0.565 \\
\hline $\mathrm{MCH}(p g)$ & $28.7(0.47)$ & $28.0(0.44)$ & $<0.001$ \\
\hline $\mathrm{MCHC}(\mathrm{g} / \mathrm{dL})$ & $35.5(0.71)$ & $35.0(0.58)$ & 0.003 \\
\hline $\operatorname{PLT}\left(\times 10^{9} / \mathrm{L}\right)$ & 431 (57.1) & 231 (44.9) & $<0.001$ \\
\hline
\end{tabular}

$S D=$ standard deviation; $W B C=$ white blood cells; $R B C=$ red blood cells; $H b=$ haemoglobin $; H c t=$ haematocrit $; M C V=$ mean corpuscular volume; $M C H=$ mean corpuscular haemoglobin; $M C H C=$ mean corpuscular haemoglobin concentration; $P L T=$ platelet count.

central nervous system (CNS) function [16]. Long-term exposure may lead to CNS damage, nosebleeds, rhinitis, halitosis, oral and nasal ulcerations, conjunctivitis, bloodshot eyes, anorexia, thirst, lethargy, weight loss and fatigue [15].

The present study showed a significant effect of LPG exposure on the haematological laboratory tests of the LPG workers as compared with controls and these results agree with studies of subjects exposed to natural gas $[17,18]$. It should be noted that there are very limited published data about the effects of long-term environmental exposure to LPG on haematological and biochemical parameters. A few studies have addressed this issue in terms of different petroleum products $[19,20]$. Other studies have addressed the haematological and biochemical effect of exposure to natural gas, which is a combustible mixture of hydrocarbon gases (formed primarily of methane, it can also include ethane, propane, butane and pentane) that is used for industrial and domestic purposes $[17,18,21]$. However, publications in 1996 and 2004 reported sudden death due to LPG inhalation, and showed that the liver and kidney were among the major organs where high concentrations of LPG accumulated $[16,22]$.

The data presented here showed that serum AST and ALT levels were significantly higher in workers than controls. Our results also agree with to the results obtained from other settings for LPG or natural gas exposures. Hu et al. showed that long-term exposure to coke oven emissions increased the risk of liver dysfunction [23], while Chen et al. and Wu et al. explored the dose-response relationship between exposure to natural gas emissions in coke oven workers and the elevation of some serum liver enzymes, and reported a significant elevation of some liver enzymes in these workers that may have been related to their exposure to natural gas $[24,25]$. Abnormal liver functions alongside neurological symptoms were reported in a case report of a male, following accidental inhalation of natural gas containing propane and butane [26].

This study showed that urea, creatinine and uric acid levels were significantly higher in workers compared with controls. Viau et al. did not find significant effects on kidney function markers of refinery workers who were occupationally exposed to hydrocarbons, the major component of natural or LPG gas [27]. To the best of our

\begin{tabular}{|c|c|c|c|}
\hline Parameter & $\begin{array}{c}\text { LPG workers } \\
\text { Mean (SD) }\end{array}$ & $\begin{array}{c}\text { Controls } \\
\text { Mean (SD) }\end{array}$ & $\begin{array}{c}P \text {-value } \\
(t \text {-test })\end{array}$ \\
\hline \multicolumn{4}{|l|}{ Liver enzymes } \\
\hline AST (U/L) & 34.7 (5.39) & $16.6(4.48)$ & 0.001 \\
\hline $\operatorname{ALT}(\mathrm{U} / \mathrm{L})$ & $32.7(4.30)$ & $14.6(4.15)$ & 0.003 \\
\hline \multicolumn{4}{|l|}{ Kidney function } \\
\hline Urea $(\mathrm{mg} / \mathrm{dL})$ & $35.6(7.93)$ & $23.6(6.59)$ & $<0.001$ \\
\hline Creatinine $(\mathrm{mg} / \mathrm{dL})$ & $1.00(0.10)$ & $0.74(0.10)$ & $<0.001$ \\
\hline Uric acid (mg/dL) & $6.17(1.01)$ & $4.01(0.43)$ & $<0.001$ \\
\hline
\end{tabular}

$S D=$ standard deviation; $A S T=$ aspartate aminotransferase, $A L T=$ alanine aminotransferase. 
knowledge and according to the international available published works, no other studies have been performed to address the effect of LPG or natural gas on kidney function tests.

Some LPG station owners did not allow us to interview the workers because of fears that the research would alert workers and lead to future fuel station inspections, and we considered this as one of the limitations of the study. In addition, the economic and siege conditions in the Gaza Strip contributed to closure of some LPG stations and laying off of LPG workers, which could be regarded as another limitation [28]. Furthermore, there were no initial health and laboratory records available for the LPG workers before being hired to their jobs. All LPG workers were assigned to the LPG stations without any medical or laboratory testing to check their fitness and suitability for duties at the LPG stations. We tried to overcome this limitation by the cross-sectional descriptive design of the study and comparing the current health status and laboratory findings of those LPG workers to their counterparts in the control group.

We can conclude that LPG workers at Gaza strip petroleum stations are at higher risk for developing health-related symptoms and clinical abnormalities due to their continuous exposure to
LPG whether as fillers or car distributors. These findings draw attention to the need for urgent policy interventions from health-related agencies in Palestine, whether governmental or nongovernmental, to improve the occupational health status of those workers by monitoring and limiting exposure to LPG. The occupational health guidelines for LPG published by the Centers for Disease Control and prevention [29] and the Environmental and Social Guidelines for Occupational Health and Safety published by the International Finance Corporation (World Bank Group) [30] could be followed for the safe use and utilization of LPG in Gaza.

\section{References}

1. Palestinian Central Bureau of Statistics. The population, housing and establishment census. Ramallah, Palestinian National Authority, 2008,

2. Yassin MM, Tubail KM, Al-Dadah JY. Towards strategies for pollution control on the use of wastewater effluent in sustainable agriculture in the Gaza Strip. World Review of Science, Technology and Sustainable Development, 2008, 5:66-78.

3. Murugkar PM et al. Hand burns sustained whilst refuelling car with LPG (liquefied petroleum gas). Burns, 2006, 32:515-516.

4. Propane Education and Research Council [website] (http:// www.usepropane.com, accessed 5 January 2013).

5. Williams $\mathrm{P}$, James R, Roberts $\mathrm{S}$, eds. Principles of toxicology: environmental and industrial applications, 2nd ed. New York, John Wiley and Sons, 2000.

6. Rom W, Markowitz S, eds. Environmental and occupational medicine. Philadelphia, Lippincott Williams and Wilkins, 2007.

7. Stellman JM, ed. Encyclopaedia of occupational health and safety, 5th ed. Geneva, International Labour Organization, 1998.

8. Thapa BR, Walia A. Liver function tests and their interpretation. Indian Journal of Pediatrics, 2007, 74:63-71.

9. Sullivan J. Krieger G, eds. Clinical environmental health and toxic exposures, 2nd ed. Philadelphia, Lippincott Williams and Wilkins, 2001.

10. Ehrenberg RL, Sniezek JE. Development of a standard questionnaire for occupational health research. American Journal of Public Health, 1989, 79 (Suppl.):15-17.

11. Munir F. The work limitation questionnaire. Occupational Medicine, 2008, 58:310-311.

12. Behera D, Jindal SK. Respiratory symptoms in Indian women using domestic cooking fuels. Chest, 1991, 100:385-388.

13. Behera D, Chakrabarti T, Khanduja KL. Effect of exposure to domestic cooking fuels on bronchial asthma. Indian Journal of Chest Diseases and Allied Sciences, 2001, 43:27-31.

14. Kumar R et al. Impact of domestic air pollution from cooking fuel on respiratory allergies in children in India. Asian Pacific Journal of Allergy and Immunology, 2008, 26:213-222.
15. Broussard L. Inhalants: classification and abuse. In: Levine B, ed. Principles of forensic toxicology. Washington DC, American Association for Clinical Chemistry, 1999.

16. Fukunaga $\mathrm{T}$ et al. Liquefied petroleum gas (LPG) poisoning: report of two cases and review of the literature. Forensic Science International, 1996, 82:193-200.

17. Saadat M, Aminollah B, Samad N. Alterations in blood pressure due to chronic exposure to natural sour gas leakage containing sulfur compounds. Biochemical and Biophysical Research Communications, 2004, 313(3):568-569.

18. Saadat M, Bahaoddini A. Hematological changes due to chronic exposure to natural gas leakage in polluted areas of Masjid-i-Sulaiman (Khozestan province, Iran). Ecotoxicology and Environmental Safety, 2004, 58:273-276.

19. Ukaejiofo EO. Biochemical and haematological assessment of workers exposed to some petroleum products in Enugu Urban, Enugu State, Nigeria. Nigerian Journal of Medicine, 2006, 15:151-155.

20. Ukaejiofo EO, Nubila T, Ike SO. Biochemical and haematological assessment of workers exposed to some petroleum products in Rnugu Urban, Rnugu State, Nigeria. Nigerian Journal of Medicine, 2006, 15:318-322.

21. Natural Gas Organization [website] (http://www.naturalgas. org/environment/naturalgas.asp, accessed 5 January 2013).

22. Sugie $\mathrm{H}$ et al. Three cases of sudden death due to butane or propane gas inhalation: analysis of tissues for gas components. Forensic Science International, 2004, 16:211-214.

23. Hu Y et al. Occupational coke oven emissions exposure and risk of abnormal liver function: modifications of body mass index and hepatitis virus infection. Occupational and Environmental Medicine, 2010, 67:159-165.

24. Chen B et al. [Elevation of some serum liver enzymes in coke oven workers and the possible relationship with exposure to polycyclic aromatic hydrocarbons]. Wei Sheng Yan Jiu, 2006, 35:264-268 [in Chinese].

25. Wu MT et al. Elevated serum liver enzymes in coke oven and by-product workers. Journal of Occupational and Environmental Medicine, 1997, 39:527-533. 
26. Pyatt JR, Gilmore I, Mullins PA. Abnormal liver function tests following inadvertent inhalation of volatile hydrocarbons. Postgraduate Medical Journal, 1998, 74:747-748.

27. Viau $\mathrm{C}$ et al. A cross-sectional survey of kidney function in refinery employees. American Journal of Industrial Medicine, 1987, 11:177-187.

28. 23 Days of War, 928 Days of Closure. Press release. Gaza, Palestinian Centre for Human Rights, 2009 (http://www.pchrgaza.
org/files/Reports/English/pdf_spec/23-days.pdf, accessed 5 January 2013).

29. Occupational health guidelines for LPG. Atlanta, Georgia, Centers for Disease Control and Prevention, 1978.

30. Environmental and social guidelines for occupational health and safety. Washington DC, International Finance Corporation, 2003.

\section{Occupational health}

Occupational health is closely linked to public health and health systems development, and WHO is addressing all determinants of workers' health, including risks for disease and injury in the occupational environment, social and individual factors, and access to health services.

WHO is implementing a Global Plan of Action on Workers' health 2008-2017 endorsed by the World Health Assembly in 2007 with the following objectives:

- devising and implementing policy instruments on workers' health;

- protecting and promoting health at the workplace;

- improving the performance of and access to occupational health services;

- providing and communicating evidence for action and practice; and

- incorporating workers' health into other policies.

Further information about the work of WHO in the area of occupational health is available at: http:/ /www. who.int/occupational_health/about/en/index.html 